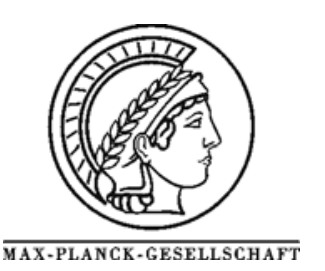

\title{
Effect of precipitate ageing on the microstructural characteristics of Cu/ZnO catalysts for methanol steam reforming
}

\author{
B.L. Kniep, F. Girgsdies, T. Ressler* \\ Department of Inorganic Chemistry, Fritz-Haber-Institute of the MPG, Faradayweg 4-6, 14195 Berlin, Germany
}

* Corresponding author: e-mail ressler@fhi-berlin.mpg.de, phone +49 308413 3192, fax +49 3084134405

Received 12 May 2005; revised 30 August 2005; accepted 1 September 2005. Available online 17 October 2005.

\begin{abstract}
Microstructural characteristics of the copper phase in $\mathrm{Cu} / \mathrm{ZnO}$ catalysts for methanol steam reforming (MSR) were investigated as a function of ageing of the precipitated hydroxycarbonates during catalyst preparation. The bulk structure of active catalysts under MSR reaction conditions was determined by in situ X-ray diffraction (XRD) and in situ X-ray absorption spectroscopy (XAS) combined with on-line mass spectrometry. Reduction kinetics and phase compositions obtained from XAS data analysis were compared to conventional TPR and TG/MS results. With increasing ageing time of the precipitate the onset of reduction of the $\mathrm{CuO} / \mathrm{ZnO}$ precursor is shifted from $462 \mathrm{~K}$ to $444 \mathrm{~K}$, while a decrease in crystallite size from $110 \AA(0 \mathrm{~min})$ to $70 \AA$ (120 min) is detected. A strong increase in catalytic activity was observed for $\mathrm{Cu} / \mathrm{ZnO}$ catalysts obtained from precipitates aged for more than $30 \mathrm{~min}$. The microstrain in the copper particles as detected by XRD and XAS was determined as an additional bulk structural parameter that correlates with the increase in catalytic activity. Moreover, continuous precipitate ageing leads to a decreasing amount of $\mathrm{Zn}$ in the copper clusters of the $\mathrm{Cu} / \mathrm{ZnO}$ catalysts. A schematic model of the structural characteristics of $\mathrm{Cu} / \mathrm{ZnO}$ catalysts as a function of precipitate ageing is proposed. The model emphasizes the defect-rich state of the homogeneous microstructure of $\mathrm{Cu} / \mathrm{ZnO}$ catalysts and its implication for the catalytic activity in the steam reforming of methanol.
\end{abstract}

Keywords: methanol, steam reforming, copper, zinc oxide, structure-activity relationship, microstrain, ageing, rational design, XAS, XRD

\section{Introduction}

$\mathrm{Cu} / \mathrm{ZnO} / \mathrm{Al}_{2} \mathrm{O}_{3}$ catalysts are industrially employed for methanol synthesis and the water gas shift reaction, and are also known to be active for the steam reforming of methanol $\left(\mathrm{CH}_{3} \mathrm{OH}+\mathrm{H}_{2} \mathrm{O} \rightarrow \mathrm{CO}_{2}+3 \mathrm{H}_{2}\right)$ [1]. In order to elucidate pathways to improved catalysts for methanol steam reforming, a fundamental understanding of the relation between surface structure, bulk structure, and catalytic activity is required. In addition to previous investigations assuming a linear correlation between the copper surface area and the catalytic activity [2], recent investigations have shown that differently prepared $\mathrm{Cu} / \mathrm{ZnO}$ catalysts may possess differently active specific copper surfaces and, thus, exhibit additional microstructural factors contributing to the correlation between surface area and catalyst performance in methanol chemistry. [3,4] Klier proposed that $\mathrm{Cu}^{+}$species dissolved in $\mathrm{ZnO}$ enhanced the catalytic activity for methanol synthesis. [5] Based on surface science investigations of model catalysts with $\mathrm{Zn}$ deposited on $\mathrm{Cu}$
(111) surfaces, Fujitani et al. [6] suggested that a metallic $\mathrm{Cu}-\mathrm{Zn}$ surface alloy is the catalytically active species for methanol synthesis. In addition to an alloying effect, dynamical and reversible changes in the morphology of the $\mathrm{Cu}$ particles may be caused by changes in the reduction potential of the gas phase (wetting /non-wetting) [7,8]. An increase in oxidation potential results in spherical $\mathrm{Cu}$ particles on large crystals of $\mathrm{ZnO}$ (i.e. non-wetting), whereas a subsequent decrease of the oxidation potential results in disc-like $\mathrm{Cu}$ particles on $\mathrm{ZnO}$ (i.e. wetting). Furthermore, it was assumed that the methanol synthesis activity is enhanced by hydrogen spill-over from $\mathrm{ZnO}$ [9].

Recently, we could show that methanol synthesis and methanol steam reforming activity of binary $\mathrm{Cu} / \mathrm{ZnO}$ catalysts with varying molar ratios correlate with the microstrain in the copper particles. [10,11] Density functional theory calculations [12] indicate, that strained copper surfaces can affect the catalytic activity because of changes in, for instance, adsorption energies and dissociation barriers of hydrogen. Defects in the bulk structure such as microstrain, impurities, and structural disorder may signifi- 
cantly influence the performance of the corresponding copper catalyst. Hence, understanding the correlations between particular preparation parameters and the microstructure of the resulting catalyst are prerequisites for a knowledgebased catalyst design. Precipitation of mixed copper-zinc hydroxycarbonates is a common method to prepare highly active $\mathrm{Cu} / \mathrm{ZnO}$ catalysts. Ageing of freshly precipitated $\mathrm{Cu}-$ Zn hydroxycarbonates exhibits a strong influence on the catalytic properties of the resulting $\mathrm{Cu} / \mathrm{ZnO}$ catalysts. An increased catalytic activity as a result of prolonged precipitate ageing was demonstrated for methanol synthesis, reverse water gas shift reaction [13], CO oxidation [14-16], and for the methanol steam reforming reaction [17]. Hence, ageing permits improving catalyst performance by tailoring the preparation conditions instead of varying the chemical composition. [17] Previous investigations concerning structural changes of the precursors during ageing in the mother liquor revealed that the initially amorphous precipitates (e.g. georgeite) transform after a certain time into a mixture of crystalline rosasite (zincian malachite) and aurichalcite [18]. While changes in the morphology of the copper catalysts obtained from aged precursors were investigated, [16] detailed bulk structure-activity relationship are not yet fully identified. This work focuses on the correlation between the increase in activity of copper catalysts prepared from aged precipitates and the structure of the copper phase of the active catalyst under working conditions. Two complementary bulk methods are employed to investigate the long-range order (in situ X-ray diffraction) and the shortrange order (in situ X-ray absorption spectroscopy) in combination with on-line mass spectrometry. A structural model of the active catalyst as function of precipitate ageing and its influence on the catalytic activity is proposed.

\section{Experimental}

\section{Preparation}

Copper zinc hydroxycarbonate precursors were prepared by co-precipitation. [18] Co-precipitation was performed in a reaction container filled with $400 \mathrm{ml}$ bidistilled water $(353 \mathrm{~K})$ by simultaneous mixing of an aqueous solution of metal nitrates $\left(\mathrm{Cu}\left(\mathrm{NO}_{3}\right)_{2} * 3 \mathrm{H}_{2} \mathrm{O}\right.$ and $\mathrm{Zn}\left(\mathrm{NO}_{3}\right)_{2} * 6 \mathrm{H}_{2} \mathrm{O}(600 \mathrm{ml}$ of a $1 \mathrm{M}$ metal nitrate solution; molar ratio of copper to zinc was 70:30 in the nitrate solution) with sodium carbonate $(1.2 \mathrm{M})$ at constant $\mathrm{pH}(\mathrm{pH} 7)$. The nitrate solution was added at constant rates of 25 $\mathrm{mL} / \mathrm{min}$. The addition rate of the precipitation reagent $\left(\mathrm{Na}_{2} \mathrm{CO}_{3}\right)$ was controlled as described in [18] to adjust the desired $\mathrm{pH}$ in the mother liquor. After complete addition of the solutions, the resulting precipitates were aged under continuous stirring in the mother liquor at $353 \mathrm{~K}$ for 15 $\mathrm{min}, 30 \mathrm{~min}$, and $120 \mathrm{~min}$. The differently aged suspension was purged out of the reactor followed by the separation of the precipitates from the mother liquor by vacuum filtration (duration of about $60 \mathrm{sec}$ ). For the 0 min aged sample, the precipitate was filtered directly after complete addition of the nitrate and soda solutions. After filtering, half of the resulting filter cake $(20 \mathrm{~g})$ was washed six times with deionized water $(80 \mathrm{ml})$ in a $250 \mathrm{ml}$ beaker for 10 min under continuous stirring at $333 \mathrm{~K}$. Finally, $3 \mathrm{~g}$ of the washed precipitate were dried at $393 \mathrm{~K}$ for $10 \mathrm{~h}$ in static air (three $\mathrm{Al}_{2} \mathrm{O}_{3}$ boats, $1 \mathrm{~g}$ precipitate each) followed by calcination at $603 \mathrm{~K}$ in static air for $3 \mathrm{~h}(6 \mathrm{~K} / \mathrm{min})$.

\section{TG/MS}

Thermogravimetric analysis was conducted during reduction on a NETSCH STA $499 \mathrm{C}$ in a constant gas flow of a 2 vol- $\% \mathrm{H}_{2}$ in helium at a total flow of $100 \mathrm{ml} / \mathrm{min}$. Approximately $15 \mathrm{mg}$ of the calcined precursors were heated in an $\mathrm{Al}_{2} \mathrm{O}_{3}$ crucible to $523 \mathrm{~K}$ with a heating ramp of $6 \mathrm{~K} / \mathrm{min}$. Evolution of gas phase composition during reduction was monitored with a quadropole mass spectrometer (Pfeiffer Omnistar).

\section{Catalytic Activity and Copper Surface Area De- termination}

Reduction of the $\mathrm{CuO} / \mathrm{ZnO}$ precursors was performed in 2 vol- $\% \mathrm{H}_{2}$ in the temperature range between 300 $\mathrm{K}$ and $523 \mathrm{~K}$ at a heating ramp of $6 \mathrm{~K} / \mathrm{min}$ followed by an isothermal period of $30 \mathrm{~min}$ at $523 \mathrm{~K}$. For in situ XRD and in situ XAS experiments, the four $\mathrm{Cu} / \mathrm{ZnO}$ samples obtained from the differently aged precursors were cooled down to $298 \mathrm{~K}$ after reduction and exposed to the steam reforming gas mixture using saturators for methanol and water (ratio $\mathrm{CH}_{3} \mathrm{OH}: \mathrm{H}_{2} \mathrm{O}=1: 1 ; \sim 2.5$ vol- $\% \mathrm{CH}_{3} \mathrm{OH} / 2.5$ vol- $\% \mathrm{H}_{2} \mathrm{O} / 95$ vol- $\% \mathrm{He}$ ) at atmospheric pressure. The temperature was increased from $298 \mathrm{~K}$ to $523 \mathrm{~K}$ with a heating ramp of $6 \mathrm{~K} / \mathrm{min}$ at a total flow of $160 \mathrm{ml} / \mathrm{min}$ in the in situ XRD cell and $40 \mathrm{ml} / \mathrm{min}$ in the in situ XAS cell. Evolution of the gas phase composition was monitored with a mass spectrometer (Pfeiffer Omnistar). $13 \mathrm{mg}$ of the catalyst sample were used for the XRD experiments, $3 \mathrm{mg}$ catalyst diluted in $30 \mathrm{mg}$ BN were used for the XAS experiments. The methanol steam reforming activity (i.e. hydrogen production rate) was calculated under isothermal conditions $(523 \mathrm{~K})$ at steady state (after $\sim 30 \mathrm{~min})$. The methanol conversion in the XAS cell amounted to $\sim 10 \%$. All $\mathrm{Cu} / \mathrm{ZnO}$ catalysts studied exhibited a spiked increase in activity followed by a decrease in activity of approximately $5 \%$ of the maximum value in a time period of $30 \mathrm{~min}$.

Catalytic activity determined in the in situ experiments was compared to activity measurements of the catalyst in a tubular stainless steel reactor placed in an aluminium-heating block. For these measurements, the catalyst powder was diluted with BN and pressed in pellets. Subsequently, the pellets were ground and sieved to obtain a defined particle size. The methanol conversion of the four catalysts obtained from differently aged precursors was determined at $523 \mathrm{~K}$ by using a Varian GC 3800 . More 

details on the experimental conditions used are given elsewhere. [19]

The specific copper surface area was determined by $\mathrm{N}_{2} \mathrm{O}$ decomposition $\left(\mathrm{N}_{2} \mathrm{O}+2 \mathrm{Cu}_{\mathrm{s}} \rightarrow \mathrm{N}_{2}+\mathrm{Cu}_{\mathrm{s}}-\mathrm{O}-\mathrm{Cu}_{\mathrm{s}}\right)[20$, 21] $\left(\mathrm{T}=313 \mathrm{~K}, 0.5\right.$ vol- $\% \mathrm{~N}_{2} \mathrm{O}$ in Helium, $\mathrm{Cu}$ surface atom density: $1,47 \times 10^{19} \mathrm{~m}^{-2}$ [22]). $50 \mathrm{mg}$ of the catalyst diluted in $50 \mathrm{mg}$ BN was placed on a quartz frit in a quartz tube reactor (bed height of about $15 \mathrm{~mm}$ ). The temperature was measured by a thermocouple positioned in the powder bed. Prior to the surface area determination the sample was reduced in $2 \mathrm{vol} \% \mathrm{H}_{2}$ (total flow of $40 \mathrm{ml} / \mathrm{min}$ ) at $523 \mathrm{~K} \mathrm{ac}$ cording to the procedure described above. After reduction the sample was cooled to $313 \mathrm{~K}$ and the reactor was purged with $\mathrm{He}$ for $1 \mathrm{~h}$. The $\mathrm{Cu}$ surface area was determined by monitoring the ion current of $\mathrm{m} / \mathrm{e}=44$ (i.e. $\mathrm{N}_{2} \mathrm{O}$ ) using a mass spectrometer. More details on the method used are given in Ref. [23].

\section{Temperature programmed reduction}

Temperature programmed reduction (TPR) was performed using a Thermoquest TPD/R/O 1100 instrument (5 $\% \mathrm{H}_{2}$ in $\mathrm{Ar}(40 \mathrm{ml} / \mathrm{min})$, heating ramp of $6 \mathrm{~K} / \mathrm{min}$ to $523 \mathrm{~K}$ followed by an isothermal period of $1 \mathrm{~h}$ at $523 \mathrm{~K}$ ). $20 \mathrm{mg}$ of the catalyst powder were diluted in $250 \mathrm{mg}$ silicon carbide (115 mesh) and placed in the reactor (bed height of about 4 $\mathrm{mm})$. Prior to the measurement, the sample was heated in $\operatorname{Ar}(20 \mathrm{ml} / \mathrm{min})$ to $423 \mathrm{~K}(10 \mathrm{~K} / \mathrm{min})$ followed by an isothermal period of $30 \mathrm{~min}$ at $423 \mathrm{~K}$.

\section{In situ X-ray diffraction}

In situ X-ray powder diffraction experiments were performed using a STOE Bragg-Brentano diffractometer $\left(\mathrm{Cu} \mathrm{K} \mathrm{K}_{\alpha}\right.$ radiation, secondary monochromator, scintillation counter). Reduction of the calcined $\mathrm{CuO} / \mathrm{ZnO}$ precursors was carried out in an in situ cell (Bühler HDK S1) as described above. XRD patterns were recorded at $523 \mathrm{~K}$ under methanol steam reforming conditions in a $2 \theta$ range from $28.0^{\circ}$ to $93.0^{\circ}$ with a step width of $0.04^{\circ}$ (counting time: 2 $\mathrm{s} / \mathrm{step}$ ). A sum of pseudo-Voigt profile functions and an appropriate background function were refined to the in situ XRD patterns of the $\mathrm{Cu} / \mathrm{ZnO}$ catalysts according to the Pawley method ("full pattern refinement"). Lattice constants of $\mathrm{Cu}$ and $\mathrm{ZnO}$, a linear zero shift in the $2 \theta$ scale, four coefficients of the background polynomial, peak intensity and Gaussian and Lorentzian part of the pseudo-Voigt profile of each individual hkl line were allowed to vary in the refinement. The volume-averaged copper crystallite size (diameter) and microstrain were determined from the Lorentzian and Gaussian part of the individual profile functions. [24] An alternative method to determine crystallite size and microstrain by analyzing X-ray diffraction line profiles is described by Williamson and Hall [25]. However, an isotropic distribution of both size and strain is a prerequisite for a linear correlation between $d^{*}=2 \sin \theta / \lambda$ and $\beta^{*}=\beta \cos \theta / \lambda$ and the applicability of the WilliamsonHall analysis.

\section{In situ X-ray absorption spectroscopy}

In situ XAS experiments were performed in a flow reactor in transmission geometry at the $\mathrm{Cu}$ K-edge $(\mathrm{E}=$ $8.979 \mathrm{keV}$ ) at the Hamburger Synchrotron Radiation Laboratory (HASYLAB, beamline $\mathrm{E} 4$ and $\mathrm{X} 1$ ). The $\mathrm{CuO} / \mathrm{ZnO}$ precursors were diluted in boron nitride and pressed for 1 min at $1.5 \mathrm{t}$ into a pellet of $5 \mathrm{~mm}$ in diameter. Reduction of the precursors was performed as described above. Timeresolved XANES (X-ray absorption near edge structure) measurements at the copper $\mathrm{K}$ edge (time resolution $=100$ s/spectrum; energy range 8.9 to $9.1 \mathrm{keV}$ ) enabled to determine phase composition and kinetics during reduction. The number of reference spectra required to reconstruct the set of experimental XANES spectra was obtained by a principle component analysis (PCA) $[26,27]$. The fraction of the reference spectra in each XANES spectrum was determined by a least-squares fit of a linear combination of the reference spectra to the experimental spectra.

After reduction of the $\mathrm{CuO} / \mathrm{ZnO}$ precursor, the extended X-ray absorption fine structure (EXAFS) of the resulting $\mathrm{Cu} / \mathrm{ZnO}$ catalyst was measured under methanol steam reforming conditions at $523 \mathrm{~K}$. A copper foil was used as reference for energy calibration. Two polynomials were employed for background subtraction and normalization, and the atomic background in the EXAFS region was determined by cubic splines. The radial distribution function was obtained by Fourier transformation of the $\mathrm{k}^{3}$ weighted experimental spectrum $\chi(\mathrm{k})$ (k range from $2.3 \AA^{-1}$ to $11.5 \AA^{-1}$ ) in the $\mathrm{R}$ space. Multiple and single scattering paths in an fcc $\mathrm{Cu}$ model structure were calculated using FEFF 8 [28] in a range from $1.5 \AA$ to $6.0 \AA$ (5\% lower limit with respect to the strongest scattering path). Refinement of the $\mathrm{Cu}$ model structure to the experimental EXAFS spectrum was carried out in R space. Structural parameters refined include the single scattering shell distances $(R)$, the Debye Waller factors of the single scattering paths $\left(\sigma^{2}\right)$, and one $\mathrm{E}_{0}$ shift for all scattering paths. The coordination numbers $(\mathrm{CN})$ were kept constant because of the rather large $\mathrm{Cu}$ crystallite sizes $(>70 \AA)$. In addition, refinement of the Debye Waller factor of a particular multiple scattering path was used as indicator for structural disorder (strain). This particular scattering path corresponds to a linear arrangement of backscatterers in the $\mathrm{Cu}$ fcc structure. Because of the so-called focusing effect, this path exhibits an exceptionally high contribution to the overall pseudo radial distribution function $\operatorname{FT}\left(\chi(\mathrm{k}) * \mathrm{k}^{3}\right)$ and is particularly susceptible to deviations from a linear arrangement (i.e. disorder and strain). 


\section{Results}

\section{Characterization of the calcined CuO/ZnO pre- cursors}

Figure 1a shows the $\mathrm{CuO}$ crystallite size of the calcined precursors $(\mathrm{CuO} / \mathrm{ZnO})$ in comparison to the $\mathrm{Cu}$ particle size of the reduced $\mathrm{Cu} / \mathrm{ZnO}$ catalyst determined by line profile analysis of XRD patterns of the precursors and the reduced $\mathrm{Cu} / \mathrm{ZnO}$ catalysts. A strong decrease in $\mathrm{CuO}$ crystallite size can be seen for the precursors obtained from crystalline precipitates (30 min and $120 \mathrm{~min}$ ageing) compared to the precursors obtained from amorphous precipitates ( 0 min and 15 min ageing). Deviations in the lattice constants of $\mathrm{CuO}$ obtained by XRD refinement of a $\mathrm{CuO}$ model structure (ICDD-PDF-2: 5-661) to the experimental patterns of the $\mathrm{CuO} / \mathrm{ZnO}$ precursors are depicted in Figure $1 \mathrm{~b}$.
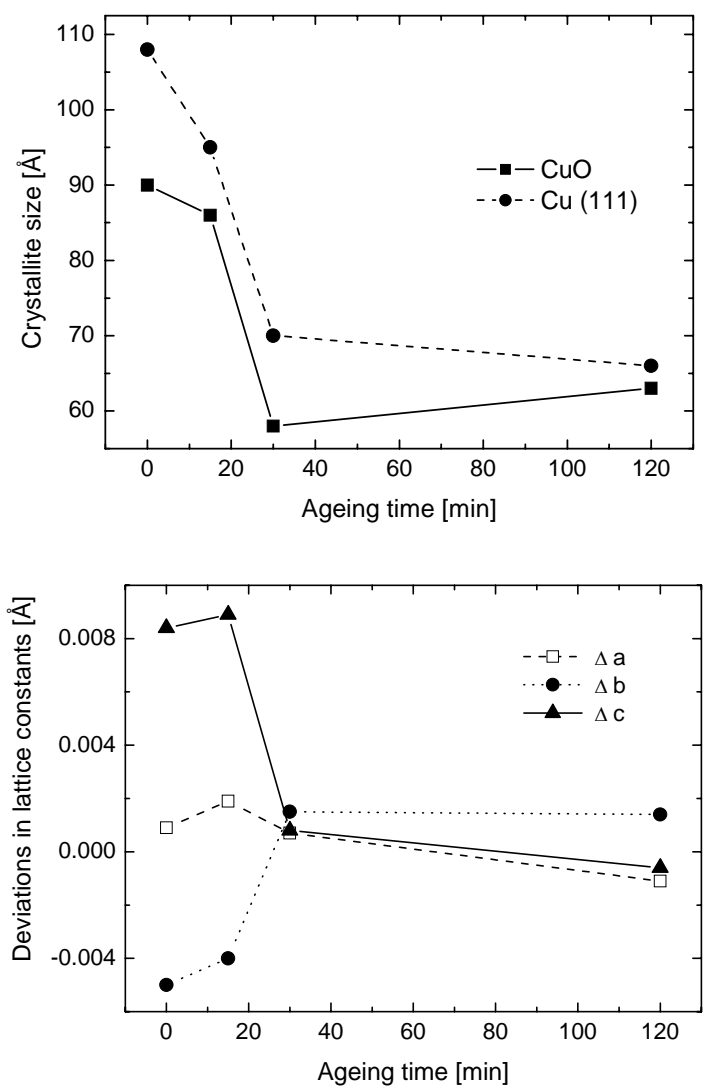

Figure 1: (a) Crystallite size of $\mathrm{CuO}$ in $\mathrm{CuO} / \mathrm{ZnO}$ precursors and of $\mathrm{Cu}$ in the reduced $\mathrm{Cu} / \mathrm{ZnO}$ catalysts as function of precipitate ageing determined from XRD line broadening. (b) Deviations in the lattice constants of $\mathrm{CuO}$ in $\mathrm{CuO} / \mathrm{ZnO}$ precursors as function of precipitate ageing.

For the $\mathrm{CuO} / \mathrm{ZnO}$ precursors obtained from precipitates aged for $0 \mathrm{~min}$ and $15 \mathrm{~min}$, the lattice constants determined deviate significantly from those of ideal $\mathrm{CuO}$. Conversely, only minor deviations in the lattice constants of $\mathrm{CuO}$ were observed for the $\mathrm{CuO} / \mathrm{ZnO}$ precursors obtained fom precipitates aged for $30 \mathrm{~min}$ and $120 \mathrm{~min}$. The distinct distortion of the $\mathrm{CuO}$ short-range structure of the $\mathrm{CuO} / \mathrm{ZnO}$ precursors obtained from precipitates aged for $0 \mathrm{~min}$ and 15 min is also visible in the $\mathrm{Cu} \mathrm{K}$ edge $\mathrm{FT}\left(\chi(\mathrm{k}) * \mathrm{k}^{3}\right)$ (Figure 2). The first peak in the $\mathrm{FT}\left(\chi(\mathrm{k}) * \mathrm{k}^{3}\right)$ which is attributed to $\mathrm{Cu}$ surrounded by oxygen in a square-planar coordination and the second peak, which is attributed to the first $\mathrm{Cu}$ shell in $\mathrm{CuO}$, exhibit a strong decrease in intensity for the precursors obtained from precipitates aged for $0 \mathrm{~min}$ and $15 \mathrm{~min}$.

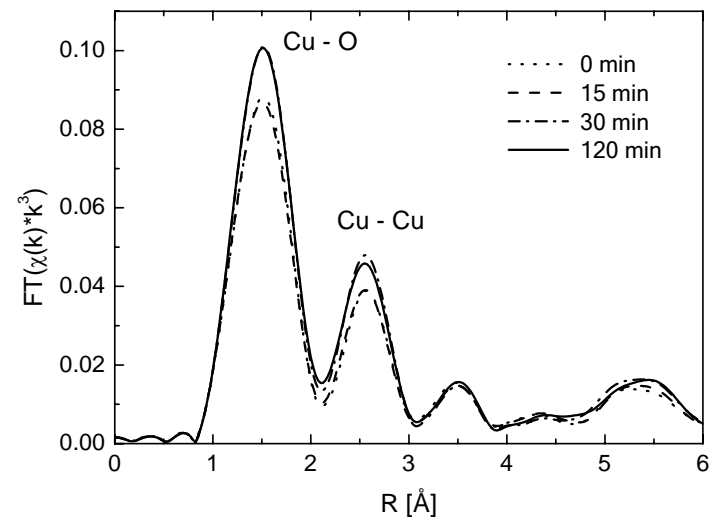

Figure 2: Experimental $\mathrm{Cu} \mathrm{K}$ edge $\mathrm{FT}\left(\chi(\mathrm{k})^{*} \mathrm{k}^{3}\right)$ of $\mathrm{CuO} / \mathrm{ZnO}$ precursors obtained from precipitates aged for 0 , 15,30 , and $120 \mathrm{~min}$.

\section{Reduction of the CuO/ZnO precursor}

The consumption of hydrogen during temperatureprogrammed reduction (TPR) of two $\mathrm{CuO} / \mathrm{ZnO}$ precursors $(0 \mathrm{~min}$ and $120 \mathrm{~min}$ ageing) in the temperature range from $300 \mathrm{~K}$ to $523 \mathrm{~K}$ is depicted in Figure 3. Both TPR traces exhibit characteristic shoulders left to the main reduction peak. Compared to the narrow reduction peak at $454 \mathrm{~K}$ of the $\mathrm{CuO} / \mathrm{ZnO}$ precursor obtained from a $120 \mathrm{~min}$ aged precipitate, the TPR traces of the $\mathrm{CuO} / \mathrm{ZnO}$ precursor obtained from a non-aged precipitate is much broader and shifted to

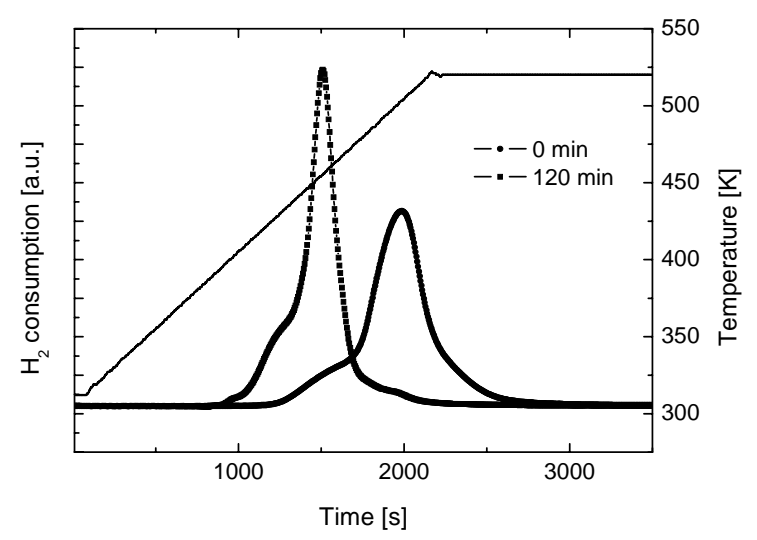

Figure 3: Hydrogen consumption during temperatureprogrammed reduction (TPR) of two $\mathrm{CuO} / \mathrm{ZnO}$ precursors ( $0 \mathrm{~min}$ and $120 \mathrm{~min}$ ageing) in the temperature range from $300 \mathrm{~K}$ to $523 \mathrm{~K}$ (heating ramp $6 \mathrm{~K} / \mathrm{min}$ ).

higher reduction temperatures $(503 \mathrm{~K})$. The onset temperature of reduction and the shape of the TPR traces of the $\mathrm{CuO} / \mathrm{ZnO}$ precursor obtained from precipitates aged for 15 $\mathrm{min}$ and $30 \mathrm{~min}$ are in good agreement with the TPR traces of the $0 \mathrm{~min}$ and $120 \mathrm{~min}$ aged precursors, respectively. 
PCA of time-resolved XANES spectra measured during reduction yielded three reference compounds $\left(\mathrm{CuO}, \mathrm{Cu}_{2} \mathrm{O}\right.$, $\mathrm{Cu}$ ) required to reconstruct the set of experimental XANES spectra. Target transformed XANES spectra of $\mathrm{CuO}$ and $\mathrm{Cu}$ are in good agreement with the first and the last experimental spectrum. Differences between the $\mathrm{Cu} \mathrm{K}$ edge spectrum of crystalline $\mathrm{Cu}_{2} \mathrm{O}$ and the corresponding targettransformed spectrum can be attributed to a different crystallite size and the high disorder of the $\mathrm{Cu}_{2} \mathrm{O}$ formed during reduction. A quantitative phase analysis was obtained from a least-squares fit of a linear combination of the $\mathrm{Cu}$ and $\mathrm{CuO}$ reference spectra and the target transformed spectra of $\mathrm{Cu}_{2} \mathrm{O}$ to each experimental XANES spectrum measured during reduction of the $\mathrm{CuO} / \mathrm{ZnO}$ precursor. The resulting evolution of the phase composition during reduction of $\mathrm{CuO} / \mathrm{ZnO}$ (15 min ageing) and the corresponding $\mathrm{H}_{2} \mathrm{O}$ evolution are shown in Figure 4. A sequential reduction pathway from $\mathrm{CuO}$ to intermediate $\mathrm{Cu}_{2} \mathrm{O}$ and, eventually, to $\mathrm{Cu}$ metal was found, which is in good agreement with previous investigations $[10,11]$.

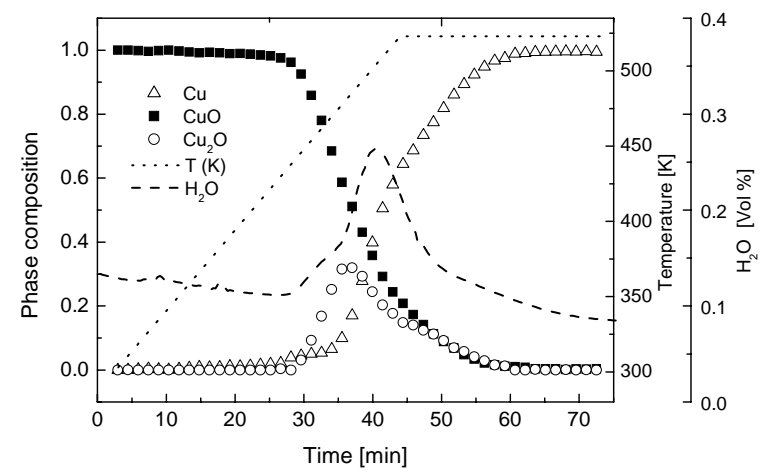

Figure 4: Evolution of phase composition $\left(\mathrm{CuO}, \mathrm{Cu}_{2} \mathrm{O}\right.$, and $\mathrm{Cu}$ ) and $\mathrm{H}_{2} \mathrm{O}$ signal during temperature-programmed reduction of a $\mathrm{CuO} / \mathrm{ZnO}$ precursor $(15 \mathrm{~min}$ aged precipitate) in $2 \% \mathrm{H}_{2}(300 \mathrm{~K}$ to $523 \mathrm{~K} ; 6 \mathrm{~K} / \mathrm{min})$ obtained from time-resolved $\mathrm{Cu} \mathrm{K}$ edge XANES measurements.

Evolution of the relative mass of the four $\mathrm{CuO} / \mathrm{ZnO}$ precursors during TPR is depicted in Figure 5. The difference in the mass loss after reduction of the $\mathrm{CuO} / \mathrm{ZnO}$ precursors obtained from precipitates aged for $120 \mathrm{~min}$ and 0 min (Figure 5) is caused by a different composition of the materials. A quantitative determination of the $\mathrm{Cu}$ content in the catalyst obtained from the copper $\mathrm{K}$ edge jump and zinc $\mathrm{K}$ edge jump exhibits a decrease in copper content from 75 mol-\% (0 min ageing) to $73 \mathrm{~mol}-\%$ copper (120 min ageing) with respect to the metals. Moreover, different amounts of residual nitrates and carbonates remain in the $\mathrm{CuO} / \mathrm{ZnO}$ precursors after preparation. The evolution of the gas phase composition during $\mathrm{TPR}$ of $\mathrm{CuO} / \mathrm{ZnO}$ obtained from precursors aged for less than 30 min clearly indicates the decomposition of residual nitrates $(\mathrm{NO}, \mathrm{m} / \mathrm{e}=30)$ and carbonates $\left(\mathrm{CO}_{2}, \mathrm{~m} / \mathrm{e}=44\right)$. The amount of residual carbonates and nitrates in the precursors decreases with increasing ageing time. Residual copper oxide phases indicating an incomplete reduction of the $\mathrm{CuO} / \mathrm{ZnO}$ precur- sors were not detected (detection limit of XAFS analysis $\sim 1$ $\%)$.

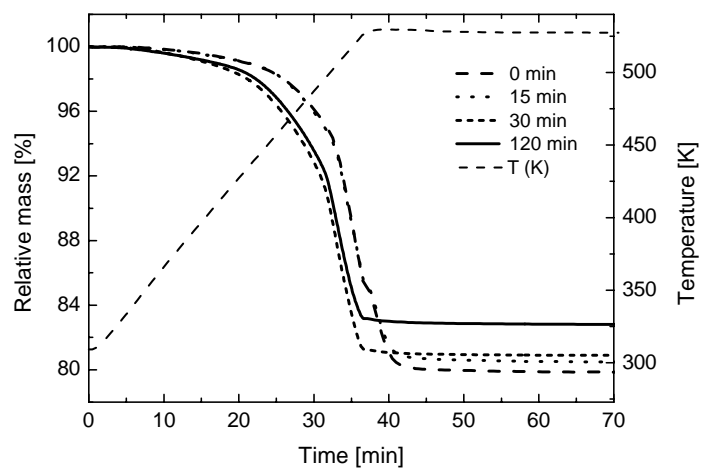

Figure 5: Evolution of relative weight during temperatureprogrammed reduction of $\mathrm{CuO} / \mathrm{ZnO}$ precursors obtained from differently aged precipitates $(0,15,30$, and $120 \mathrm{~min})$ $\left(2 \% \mathrm{H}_{2}, 300 \mathrm{~K}\right.$ to $\left.523 \mathrm{~K} ; 6 \mathrm{~K} / \mathrm{min}\right)$.

\section{Methanol steam reforming on $\mathrm{Cu} / \mathrm{ZnO}$ catalysts}

The $\mathrm{H}_{2}$ production rate during methanol steam reforming on the $\mathrm{Cu} / \mathrm{ZnO}$ catalysts as determined in the in situ XAS cell and the methanol conversion as determined in the tubular reactor as a function of ageing time are compared in Figure 6. The activity of the $\mathrm{Cu} / \mathrm{ZnO}$ catalysts in the tubular reactor strongly increased between $15 \mathrm{~min}$ and 30 min ageing time from initially $36 \%$ methanol conversion (XAS cell: $600 \mu \mathrm{mol} / \mathrm{g} * \mathrm{~s} \mathrm{H}_{2}$ prod. rate; $15 \mathrm{~min}$ ageing) to $60 \%$ conversion (XAS cell: $900 \mu \mathrm{mol} / \mathrm{g} *_{\mathrm{s}} \mathrm{H}_{2}$ prod. rate; $30 \mathrm{~min}$ ageing). A similar dependence of the methanol steam reforming activity of the $\mathrm{Cu} / \mathrm{ZnO}$ catalysts on the ageing time was found for the in situ XRD experiments. The good agreement between the catalytic performance measured in the in situ XAS cell and the steel reactor (Figure 6) indicates that the structural data obtained from in situ XAS experiments under conditions of differential conversion $(\sim 10 \%$ methanol conversion in XAS cell) permit deducing reliable structure-activity relationships.

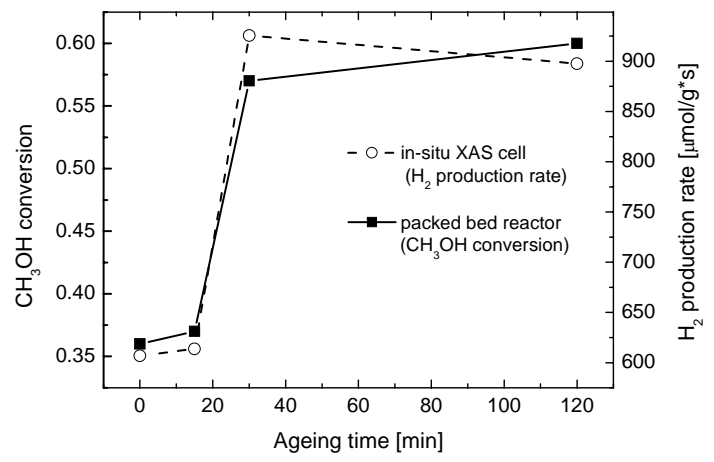

Figure 6: Methanol steam reforming activity of $\mathrm{Cu} / \mathrm{ZnO}$ catalysts at $523 \mathrm{~K}$ as a function of precipitate ageing. The methanol conversion determined in a packed bed reactor is depicted in comparison to the $\mathrm{H}_{2}$ production rate obtained during the in situ XAS experiment. 


\section{Long-range order from in situ X-ray diffraction}
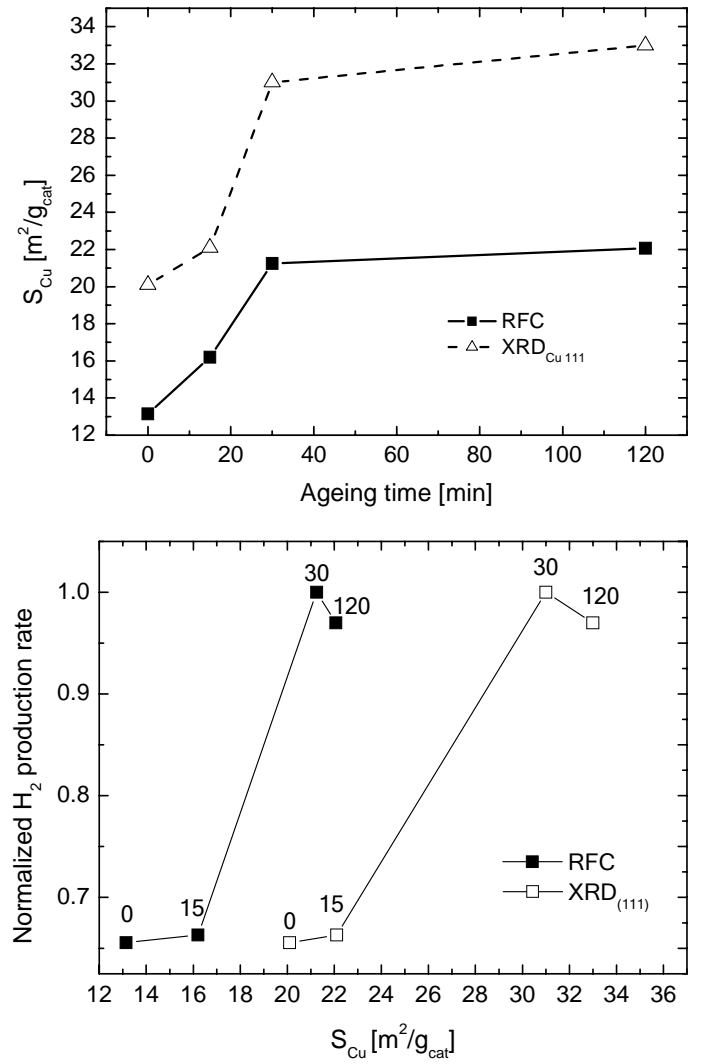

Figure 7: (a) Specific copper surface area of $\mathrm{Cu} / \mathrm{ZnO}$ catalysts as a function of precursor ageing determined by $\mathrm{N}_{2} \mathrm{O}$ titration and estimated from the XRD copper particle size (Figure 8, $\mathrm{Cu}$ 111). (b) Normalized $\mathrm{H}_{2}$ production rate according to Figure 6 as a function of the specific copper surface area.

In Figure 7, the specific copper surface areas as determined by $\mathrm{N}_{2} \mathrm{O}$ decomposition are compared to those calculated from the respective volume-averaged copper crystallite size (i.e. diameter, XRD) assuming spherical crystallites. An increasing ageing time resulted in an increase in the $\mathrm{Cu}$ surface area from initially $13 \mathrm{~m}^{2} / \mathrm{g}_{\text {cat }}$ after $0 \mathrm{~min}$ ageing $\left(20 \mathrm{~m}^{2} / \mathrm{g}_{\text {cat }}\right.$ by XRD) to $21 \mathrm{~m}^{2} / \mathrm{g}_{\text {cat }}$ after 120 min ageing $\left(33 \mathrm{~m}^{2} / \mathrm{g}_{\text {cat }}\right.$ by XRD). Both methods revealed similar trends in the evolution of the $\mathrm{Cu}$ surface area as a function of precipitate ageing. $\mathrm{Cu} / \mathrm{ZnO}$ support interactions that reduce the accessible $\mathrm{Cu}$ surface area and a nonspherical morphology of the $\mathrm{Cu}$ particles may account for the deviations in the $\mathrm{Cu}$ surface areas obtained, in addition to a bimodal particle size distribution or re-oxidation of partially reduced $\mathrm{ZnO}$. The normalized $\mathrm{H}_{2}$ production rates measured during the in situ XAS measurements as a function of the specific $\mathrm{Cu}$ surface area are depicted in Figure 7b. The $\mathrm{H}_{2}$ production rate is normalized to the activity of the most active catalyst in the steam reforming of methanol (30 min ageing).
Quantitative phase analysis of the in situ XRD patterns of the reduced $\mathrm{Cu} / \mathrm{ZnO}$ catalysts $(0,15,30$, and 120 min) measured under steam reforming conditions at $523 \mathrm{~K}$ revealed a phase composition of 68 mol- $\%$ copper and 32 mol- $\%$ zinc oxide [17]. While the phase composition of the four $\mathrm{Cu} / \mathrm{ZnO}$ catalysts was very similar, the profiles of the individual copper diffraction lines in the patterns of the catalysts exhibited significant differences. Analysis of the $\mathrm{Cu}$ (111) line profile as a function of precipitate ageing revealed a decrease of the copper crystallite size from initially $110 \AA$ ( 0 min ageing) to $70 \AA$ (120 min ageing) (Figure $8 \mathrm{~b})$ accompanied by an increase in copper microstrain from initially $0.09 \%$ (0 $\mathrm{min}$ ageing) to $0.25 \%$ (120 $\mathrm{min}$ ageing) (Figure 8a). [17] In comparison, copper particles obtained from the reduction of $\mathrm{CuO}$ (obtained by calcination of malachite, $\left.\mathrm{Cu}_{2}(\mathrm{OH})_{2}\left(\mathrm{CO}_{3}\right)\right)$ exhibited a particle size of $300 \AA$ and a microstrain of $0.06 \%$.
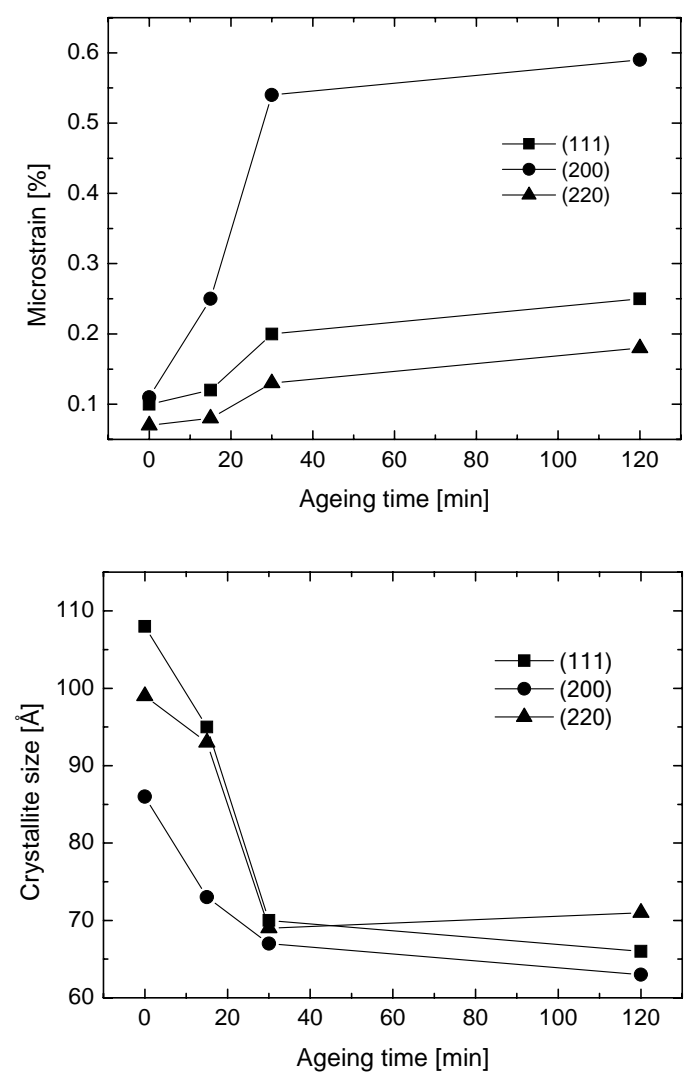

Figure 8: (a) Copper microstrain (b) and crystallite size as function of precipitate ageing determined from the $\mathrm{Cu} 111$, 200 , and $220 \mathrm{XRD}$ lines of $\mathrm{Cu} / \mathrm{ZnO}$ catalysts under methanol steam reforming conditions at $523 \mathrm{~K}$.

Crystallite size and microstrain obtained from the analysis of three different copper diffraction lines (111, $200,220)$ as function of precipitate ageing is shown in Figure $8 \mathrm{a}$ and $8 \mathrm{~b}$. Distinct deviations in both crystallite size and microstrain obtained from different copper lattice planes can be seen. The $\mathrm{Cu} / \mathrm{ZnO}$ samples analyzed here exhibited a preferred orientation in the [111] direction and a maximum in microstrain in the [100] direction. Neverthe- 
less, a decrease in crystallite size and an increase in microstrain as a function of precipitate ageing were observed for all individual copper diffraction lines. A WilliamsonHall plot based on the XRD patterns of the four $\mathrm{Cu} / \mathrm{ZnO}$ catalysts confirmed the strong anisotropy (non-linearity between $\beta^{*}$ and $d^{*}$ ) in the $\mathrm{Cu} / \mathrm{ZnO}$ catalysts visible in Figure 8 . Hence, the crystallite size and the microstrain had to be determined by analyzing individual X-ray diffraction lines.

\section{Short-range order from in situ $X$-ray absorption spectroscopy}

X-ray absorption spectra of the $\mathrm{Cu} / \mathrm{ZnO}$ catalysts were measured at the $\mathrm{Cu} \mathrm{K}$ edge under methanol steam reforming reaction conditions at $523 \mathrm{~K}$. The resulting pseudo radial distribution functions $\left(\mathrm{FT}\left(\chi(\mathrm{k}) * \mathrm{k}^{3}\right)\right)$ of the four $\mathrm{Cu} / \mathrm{ZnO}$ catalysts obtained from differently aged precipitates are compared in Figure 9. The $\mathrm{FT}\left(\chi(\mathrm{k}) * \mathrm{k}^{3}\right)$ of the catalysts are very similar above $3 \AA$, whereas the peak at $\mathrm{R}$ $=2.2 \AA$ (not phase-shift corrected), which is attributed to the first $\mathrm{Cu}-\mathrm{Cu}$ distance in fcc copper metal, exhibits a strong increase in amplitude with increasing ageing time.

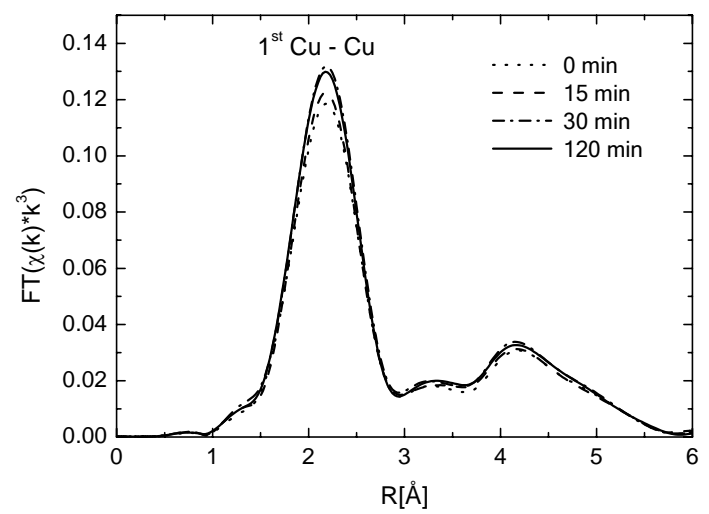

Figure 9: Experimental $\mathrm{Cu} \mathrm{K}$ edge $\mathrm{FT}\left(\chi(\mathrm{k})^{*} \mathrm{k}^{3}\right)$ of $\mathrm{Cu} / \mathrm{ZnO}$ catalysts obtained from precipitates aged for $0,15,30$ and 120 min under methanol steam reforming conditions at 523 $\mathrm{K}$.

The result of a refinement of the $\mathrm{Cu}$ fcc model structure to the experimental $\mathrm{Cu} \mathrm{FT}\left(\chi(\mathrm{k}) * \mathrm{k}^{3}\right)$ of a $\mathrm{Cu} / \mathrm{ZnO}$ catalyst (120 min ageing) together with the linear focusing multiple scattering paths are shown in Figure 10. The good agreement between theory and experiment indicates that no additional phases (e.g. copper oxides) are detectable in the EXAFS spectrum. The Debye-Waller factor of the multiple scattering path (Figure 10) used to estimate the amount of microstrain in the $\mathrm{Cu} / \mathrm{ZnO}$ catalysts is given in Figure 11. An increase in the Debye Waller factor with ageing time is detected. Conversely, the simultaneous decrease of the amount of $\mathrm{Zn}$ in the copper phase should yield a decrease in the Debye-Waller factor (i.e. an increase in amplitude) as seen in the first $\mathrm{Cu}$ shell of the corresponding $\mathrm{Cu} / \mathrm{ZnO}$ catalysts (Figure 9). Therefore, the behavior of the particular "focusing" multiple scattering path as a probe for mi- crostrain in the copper phase is in good agreement with the increase of microstrain as a function of precipitate ageing as obtained by XRD line profile analysis.

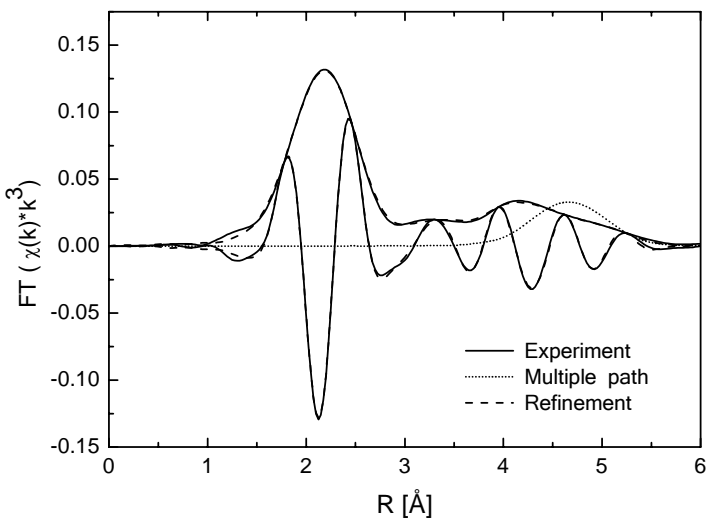

Figure 10: Refinement of a theoretical EXAFS function (dashed) to the experimental Cu K edge $\mathrm{FT}\left(\chi(\mathrm{k}) * \mathrm{k}^{3}\right)$ (solid) of a $\mathrm{Cu} / \mathrm{ZnO}$ catalyst (120 min ageing) under methanol steam reforming conditions at $523 \mathrm{~K}$. The four most prominent single-scattering paths (dotted) in the EXAFS function together with one multiple-scattering path (arrow in unit cell) are depicted.

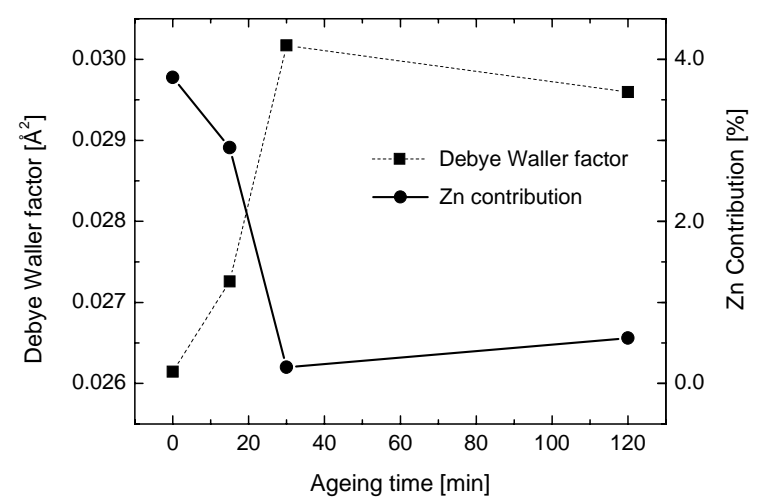

Figure 11: Debye-Waller factors of the multiple-scattering path indicated by the arrow in Figure 10 as function of precipitate ageing obtained by refinement of a theoretical $\mathrm{Cu}$ EXAFS function to the experimental $\mathrm{FT}\left(\chi(\mathrm{k}) * \mathrm{k}^{3}\right)$ of four $\mathrm{Cu} / \mathrm{ZnO}$ catalysts $(0,15,30$, and $120 \mathrm{~min}$ ageing) measured at $523 \mathrm{~K}$ together with (b) the contribution of a $\mathrm{Cu}-\mathrm{Zn}$ shell to the $\mathrm{Cu} \mathrm{K}$ edge $\mathrm{FT}\left(\chi(\mathrm{k}) * \mathrm{k}^{3}\right)$ of the $\mathrm{Cu} / \mathrm{ZnO}$ catalysts as function of precipitate ageing.

In addition, the distances of the first $\mathrm{Cu}$ shell in the four $\mathrm{FT}\left(\chi(\mathrm{k}) * \mathrm{k}^{3}\right)$ of the $\mathrm{Cu} / \mathrm{ZnO}$ catalysts were obtained from the EXAFS analysis. Figure 12 shows the evolution of the deviations in the distance of the first $\mathrm{Cu}$ shell (relative to $\mathrm{a}=3.615 \AA$ for bulk fcc copper metal) in comparison to the copper lattice constants determined by XRD refinement. The decrease in the distance of the first $\mathrm{Cu}$ shell coincides with the decrease in copper lattice constant with ageing time. The lattice expansion of the $\mathrm{Cu}$ crystallites in the $\mathrm{Cu} / \mathrm{ZnO}$ catalysts obtained from precipitates aged for 0 min and 15 min may indicate the presence of $\mathrm{Zn}$ occupying copper lattice sites as previously observed in $\mathrm{Cu} / \mathrm{ZnO}$ catalysts with varying molar ratios. [11] In order to quantify the amount of $\mathrm{Zn}$ in the $\mathrm{Cu}$ nanoparticles, an additional $\mathrm{Zn}$ 


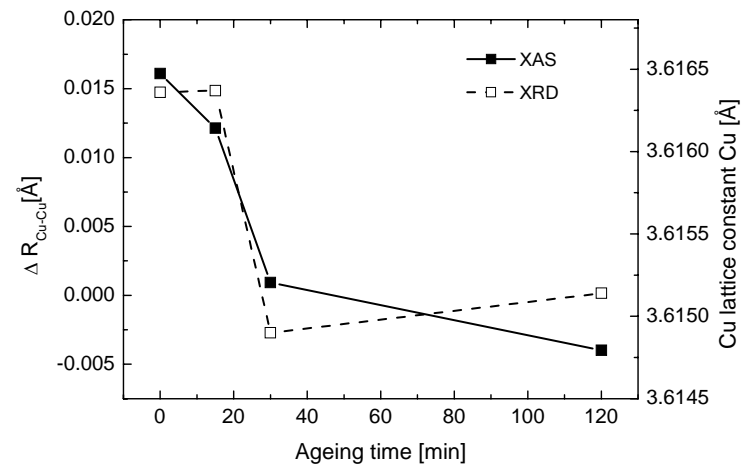

Figure 12: Variation of the $\mathrm{Cu}$ lattice parameter determined by XRD under methanol steam reforming conditions at $523 \mathrm{~K}$ and deviations in the distance of the first $\mathrm{Cu}$ shell obtained from an EXAFS refinement to the experimental $\mathrm{Cu} \mathrm{K}$ edge $\mathrm{FT}\left(\chi(\mathrm{k}) * \mathrm{k}^{3}\right)$ as a function of precipitate ageing.

shell at a $\mathrm{Cu}-\mathrm{Zn}$ distance of $2.66 \AA$ [8] was included in the EXAFS refinement. The distances of the $\mathrm{Cu}-\mathrm{Cu}$ and the $\mathrm{Cu}-\mathrm{Zn}$ scattering paths were kept constant, while the sum of the coordination numbers of the $\mathrm{Cu}-\mathrm{Cu}$ and $\mathrm{Cu}-\mathrm{Zn}$ scattering paths was constrained to be 12 in the refinement. The amount of $\mathrm{Zn}$ scatterers necessary to simulate the first shell of the experimental spectra of the four $\mathrm{Cu} / \mathrm{ZnO}$ catalysts is shown in Figure 11 indicating a decreasing amount of $\mathrm{Zn}$ occupying $\mathrm{Cu}$ lattice sites in the catalysts obtained from precipitates aged for $30 \mathrm{~min}$ and $120 \mathrm{~min}$. The increase in $\mathrm{Cu}-\mathrm{Cu}$ distance of $\sim 0.016 \AA$ in the $\mathrm{Cu} / \mathrm{ZnO}$ catalysts obtained from short-aged precipitates is about one order of magnitude larger than the corresponding lattice expansion of $0.0014 \AA$ as detected by XRD. This discrepancy may be accounted for by the XAFS refinement procedure employed, which considers an average of the $\mathrm{Cu}-\mathrm{Cu}$ distance $\left(\mathrm{R}_{\mathrm{Cu}-\mathrm{Cu}}=2.55 \AA\right)$ and the $\mathrm{Cu}-\mathrm{Zn}$ distance $\left(\mathrm{R}_{\mathrm{Cu}-\mathrm{Zn}}=2.66 \AA\right)$ in the first shell. This may result in larger distance deviations in the short-range order compared to the long-range lattice expansion as determined by XRD.

\section{Discussion}

\section{Structure of the CuO/ZnO precursors}

The long-range (Figure 1) and short-range structure (Figure 2) of the four $\mathrm{CuO} / \mathrm{ZnO}$ precursors exhibit a characteristic dependence on the crystallization of the initially amorphous precipitates that occurs after about $30 \mathrm{~min}$ ageing. [18] The decrease in the $\mathrm{CuO}$ crystallite size of the calcined $\mathrm{CuO} / \mathrm{ZnO}$ precursor with increasing ageing time coincides with the decreasing $\mathrm{Cu}$ crystallite size of the reduced $\mathrm{Cu} / \mathrm{ZnO}$ catalysts (Figure 1a). Moreover, the $\mathrm{CuO}$ lattice constants of $\mathrm{CuO} / \mathrm{ZnO}$ precursors obtained from precipitates aged for $30 \mathrm{~min}$ or $120 \mathrm{~min}$ show a remarkable shift towards those of regular $\mathrm{CuO}$ (Figure 1b). The deviations in the $\mathrm{CuO}$ lattice constants of $\mathrm{CuO} / \mathrm{ZnO}$ precursors obtained from short-aged precipitates ( $0 \mathrm{~min}$ and $15 \mathrm{~min}$ ) can be assigned to the formation of a $\mathrm{Zn}$-doped $\mathrm{CuO}\left(\mathrm{Cu}_{1-}\right.$ $\left.{ }_{\mathrm{x}} \mathrm{Zn}_{\mathrm{x}} \mathrm{O}\right) .[29,30]$
The deviations in the short-range order structure of the $\mathrm{CuO} / \mathrm{ZnO}$ precursors obtained from short-aged and long-aged precipitates are in good agreement with the corresponding long-range order structure of the materials (Figure 2). The first peak in the XAFS FT $\left(\chi(\mathrm{k})^{*} \mathrm{k}^{3}\right)$ which corresponds to four oxygen atoms in a square-planar coordination and the second peak, which corresponds to the first $\mathrm{Cu}$ shell in $\mathrm{CuO}$, (Figure 2) exhibit a strong increase in intensity for the precursors obtained from precipitates aged for $30 \mathrm{~min}$ and $120 \mathrm{~min}$. A similar increase is also visible in the $\mathrm{FT}\left(\chi(\mathrm{k}) * \mathrm{k}^{3}\right)$ of the corresponding reduced $\mathrm{Cu} / \mathrm{ZnO}$ catalysts (Figure 9). The increase in $\operatorname{FT}\left(\chi(\mathrm{k}) * \mathrm{k}^{3}\right)$ amplitude of the $\mathrm{CuO} / \mathrm{ZnO}$ precursor and the $\mathrm{Cu} / \mathrm{ZnO}$ catalysts may be explained by (i) an unlikely decrease in the DebyeWaller factor, which at least for the $\mathrm{Cu} / \mathrm{ZnO}$ catalysts is in contrast to the increase in microstrain detected by XRD and NMR [17], (ii) an increase in the apparent coordination number because of changes in crystallite size, which can be excluded because of the rather large crystallites ( $>70 \AA$ [31]) and the overall decrease in crystallite size with ageing, or most likely (iii) a decreasing amount of $\mathrm{Zn}$ in the $\mathrm{CuO}$ phase and the resulting copper catalyst. Hence, it may be concluded that the deviations in the "real" structure of $\mathrm{CuO}$ in the calcined precursors obtained from short-aged precipitates (Figure $1 \mathrm{~b}$ and Figure 2 ) are caused by $\mathrm{Zn}$ centers in the $\mathrm{CuO}$ structure. Similarly, $\mathrm{Zn}$ in the calcined $\mathrm{CuO} / \mathrm{ZnO}$ precursors was proposed for $\mathrm{Cu} / \mathrm{ZnO}$ catalysts with various $\mathrm{Cu}$ to $\mathrm{Zn}$ ratios. [10]

\section{Reduction of the CuO/ZnO precursors}

The four $\mathrm{CuO} / \mathrm{ZnO}$ precursors studied can be separated into two groups with respect to the onset temperature of reduction (Figure 3 and Figure 5). $\mathrm{CuO} / \mathrm{ZnO}$ precursors obtained from precipitates aged for $0 \mathrm{~min}$ and $15 \mathrm{~min}$ exhibit a higher onset of reduction $(\sim 450 \mathrm{~K})$, compared to precursors obtained from precipitates aged for $30 \mathrm{~min}$ and $120 \mathrm{~min}(\sim 500 \mathrm{~K})$. The lower reduction temperature of the precursors obtained from long-aged precipitates compared to those obtained from short-aged precipitates is caused by the smaller $\mathrm{CuO}$ crystallite size ( $\sim 60 \AA$ and $\sim 90 \AA$, respectively (Figure 1a.)) the higher amount of strain and disorder, and the more homogeneous microstructure. [32] The increase in crystallite size during reduction of the non-aged $\mathrm{CuO} / \mathrm{ZnO}$ precursor $(\sim 90 \AA)$ to the corresponding $\mathrm{Cu} / \mathrm{ZnO}$ catalyst $(\sim 110 \AA)$ indicates a pronounced sintering of the copper particles. Similar to the increased onset of reduction, this lowered stability towards sintering is consistent with the larger amount of isolated copper particles and the diminished interface between $\mathrm{Cu}$ and $\mathrm{ZnO}$ in the catalysts obtained from short-aged precipitates. [32] Conversely, the more homogenous particle size distribution and the improved interface between copper and zinc oxide in the $\mathrm{Cu} / \mathrm{ZnO}$ catalysts obtained from long-aged precipitates increase the degree of dispersion and prevent sintering of the copper particles during reduction $(\sim 65 \AA$ for $\mathrm{Cu}$ and $\mathrm{CuO}$ ) (Figure 1a). 
A quantitative XANES analysis (Figure 4) permits to assign a sequential reduction pathway to the two peaks observed during TPR (Figure 3) according to $\mathrm{CuO} \rightarrow \mathrm{Cu}_{2} \mathrm{O}$ $\rightarrow \mathrm{Cu}$. This is in good agreement with previous reports on the reduction of $\mathrm{CuO}$ in the $\mathrm{CuO} / \mathrm{ZnO} / \mathrm{ZrO}_{2}$ system [33] and the reduction of $\mathrm{CuO}$ and $\mathrm{Cu}_{2} \mathrm{O}$ in $\mathrm{H}_{2}$ [34]. Furthermore, it can be seen that the $\mathrm{H}_{2} \mathrm{O}$ evolution measured during the in situ XAFS experiments correlates with the phase composition during reduction (Figure 4) and the TPR measurements (Figure 3). The first maximum in the $\mathrm{H}_{2} \mathrm{O}$ evolution indicates the formation of intermediate $\mathrm{Cu}_{2} \mathrm{O}$, while the second maximum corresponds to the formation of $\mathrm{Cu}$ metal.

The narrow TPR peak of the aged precursor (Figure 3 ) is in good agreement with the homogeneous microstructure of the corresponding single-phase $\mathrm{Cu} / \mathrm{ZnO}$ catalyst. [32] The heterogeneous microstructure of the $\mathrm{Cu} / \mathrm{ZnO}$ catalysts obtained from non-aged precipitates can already be inferred from the broad high-temperature TPR peak of the corresponding $\mathrm{CuO} / \mathrm{ZnO}$ precursor. The characteristic grouping of the $\mathrm{CuO} / \mathrm{ZnO}$ precursors obtained from shortaged ( 0 and $15 \mathrm{~min})$ and long-aged (30 and $120 \mathrm{~min})$ precipitates clearly reflects the dominant influence of the ageing procedure not only on the structure of the precipitate but also on the structure of the $\mathrm{CuO} / \mathrm{ZnO}$ precursors (Figure 1 and Figure 2), the reduction behavior (Figure 3 and Figure 5), and, eventually, the resulting $\mathrm{Cu} / \mathrm{ZnO}$ catalyst (Figure 6). The $\mathrm{CuO} / \mathrm{ZnO}$ precursors and the $\mathrm{Cu} / \mathrm{ZnO}$ catalysts exhibit a "chemical memory" on the ageing of the hydroxycarbonates during the first stages of preparation and neither calcination nor reduction appear to erase the characteristic structural differences.

\section{Correlations between copper structure and MSR activity}

The crystalline hydroxycarbonate precipitates obtained after prolonged ageing result in $\mathrm{Cu} / \mathrm{ZnO}$ catalysts that show a pronounced increase in MSR activity compared to the catalysts obtained from amorphous precipitates (Figure 6). The $\mathrm{Cu} / \mathrm{ZnO}$ catalysts obtained from long-aged precipitates exhibit a smaller copper crystallite size (Figure 8b) and a larger copper surface area (Figure 7a). Figure $7 b$ shows a nearly linear correlation between normalized activity of the catalysts and the specific $\mathrm{Cu}$ surface area. Apparently, the specific copper surface area is the dominating factor for structure-activity correlations of $\mathrm{Cu} / \mathrm{ZnO}$ catalysts. However, more evident examples for a non-linear behavior of activity and $\mathrm{Cu}$ surface area have been shown recently, [35] indicating that additional structural parameters govern the activity of the specific copper surface. The structural and catalytic properties of the $\mathrm{Cu} / \mathrm{ZnO}$ materials studied confirm that in addition to the copper surface area, the increased microstrain in the nanostructured $\mathrm{Cu}$ particles as detectable by XRD (Figure 8a) and XAS (Figure 11) correlates with the improved MSR activity of $\mathrm{Cu} / \mathrm{ZnO}$. Evaluation of various XRD lines in the patterns of the re- duced $\mathrm{Cu} / \mathrm{ZnO}$ catalysts revealed a strong anisotropy in $\mathrm{Cu}$ particle size and microstrain (Figure 8). TEM images of the $\mathrm{Cu} / \mathrm{ZnO}$ catalysts described here show a number of epitaxial relations between $\mathrm{Cu}$ and $\mathrm{ZnO}$ (e.g. $\mathrm{Cu}[111]|| \mathrm{ZnO}$ [110]), [32] which explains the anisotropic distribution of microstrain in the copper particles. The anisotropy in copper crystallite size appears to be more pronounced for the catalysts obtained from short-aged precipitates (Figure 8), which is consistent with the heterogeneous microstructure of these materials. In addition to determining the microstrain in the copper nanoparticles by in situ XRD (Figure 8) and EXAFS (Figure 11), we could show that ex situ ${ }^{63} \mathrm{Cu}$ nuclear magnetic resonance (NMR) spectroscopy investigations of the freshly reduced catalysts are in good agreement with the XRD results concerning the evolution of copper particle size and microstrain as a function of precipitate ageing. [17] Moreover, tensile strain in the $\mathrm{Cu}$ nanoclusters was also reported by Wagner et al. based on $\mathrm{Cu} \mathrm{L}_{\mathrm{III}}$ edge ELNES measurements of $\mathrm{Cu} / \mathrm{ZnO}$ model catalysts. [36] However, with a combined change in crystallite size, composition (i.e. $\mathrm{Zn}$ content), and microstrain as a function of precipitate ageing, the catalysts studied here are not suitable to unambiguously address the correlation between strain in copper and catalytic activity. Using other model systems, such as the recently reported thin $\mathrm{Cu}$ films on $\mathrm{Si}$, [37] it may be feasible to unravel the effect of strain on the electronic structure of $\mathrm{Cu}$ and, thus, on the catalytic activity.

The correlation between microstrain in the copper nanoparticles (Figure 8a) and catalytic properties (Figure 6) clearly indicates that the improved interface between $\mathrm{Cu}$ and $\mathrm{ZnO}$ in the long-aged catalysts has a considerable influence on the microstructure of the $\mathrm{Cu}$ nanoparticles. [32] Moreover, it emphasizes the role of $\mathrm{ZnO}$ in determining the microstructure of the copper phase in addition to dispersing the copper particles and reduce sintering. The characteristic crystallization of the hydroxycarbonate precipitates during ageing coincides with the increase in activity of the resulting $\mathrm{Cu} / \mathrm{ZnO}$ catalysts (Figure 6). TEM investigations show that calcination of the amorphous precipitates results in a heterogeneous microstructure with a majority of separated $\mathrm{Cu}$ and $\mathrm{ZnO}$ crystallites and, hence, a less active $\mathrm{Cu} / \mathrm{ZnO}$ catalyst upon reduction. Conversely, calcination and reduction of the crystalline precipitates obtained after ageing yields catalysts where $\mathrm{Cu}$ and $\mathrm{ZnO}$ are distributed in a homogeneous microstructure with small and disordered $\mathrm{Cu}$ crystallites possessing a distinct interface with $\mathrm{ZnO}$. [32]

In addition to the microstrain detected in the copper particles, the presence of $\mathrm{Zn}$ in both the $\mathrm{CuO}$ in the precursor and the $\mathrm{Cu}$ in the resulting catalyst emphasize the defect-rich state of the "real" structure of the copper phase in $\mathrm{Cu} / \mathrm{ZnO}$ catalysts (Figure 11). The increase in the copper lattice constant $(\sim 3.616 \AA)$ and the distance of the first $\mathrm{Cu}$ shell (Figure 12) of $\mathrm{Cu} / \mathrm{ZnO}$ catalysts obtained from shortaged precipitates indicates a larger amount of $\mathrm{Zn}$ in the copper phase compared to the $\mathrm{Cu} / \mathrm{ZnO}$ catalysts obtained from long-aged precipitates (Figure 11). $\alpha$-brass (i.e. $\mathrm{Cu} \mathrm{Zn}$ alloy) formation should only occur at temperatures above 
$580 \mathrm{~K}$. [3] At a temperature of $523 \mathrm{~K}$ the concentration of $\mathrm{Zn}$ in $\mathrm{Cu}$ amounts to about $1 \% \mathrm{Zn}$ [38]. A higher oxygen vacancies concentration at the $\mathrm{ZnO}$ surface may increase the tendency of $\alpha$-brass formation in the copper bulk due to an enhanced diffusion rate through the $\mathrm{Cu} / \mathrm{ZnO}$ interface and an improved miscibility of $\mathrm{Cu}$ and $\mathrm{Zn}$ in the real structure of the $\mathrm{Cu} / \mathrm{ZnO}$ catalyst. It is more likely though, that the formation of $\alpha$-brass during reduction at $523 \mathrm{~K}$ results from the presence of $\mathrm{Zn}$ in the $\mathrm{CuO}$ phase in the $\mathrm{CuO} / \mathrm{ZnO}$ precursors (Figure 1 and Figure 2). It is evident from Figure 11 that the amount of $\mathrm{Zn}$ in the copper nanoparticles exhibits a negative correlation with the microstrain in the copper phase and the performance of the $\mathrm{Cu} / \mathrm{ZnO}$ catalysts (Figure 6). Apparently, the presence of $\mathrm{Zn}$ in the copper particles is not the main source of the microstrain observed and is not required in the "real" structure of a more active $\mathrm{Cu} / \mathrm{ZnO}$ catalyst.

\section{Model of nanostructured Cu/ZnO catalysts as function of precipitate ageing}

The effect of precipitate ageing on the microstructural properties of the resulting $\mathrm{Cu} / \mathrm{ZnO}$ catalyst is schematically depicted in Figure 13. The short-aged precipitates ( $0 \mathrm{~min}$ and $15 \mathrm{~min}$ ) exhibit on average larger $\mathrm{Cu}$ and $\mathrm{ZnO}$ particles upon calcination and reduction (Figure 8), which are more separated in these materials and possess a reduced $\mathrm{Cu} / \mathrm{ZnO}$ interface. Assuming that copper microstrain originates from an epitaxial orientation of copper on $\mathrm{ZnO}$, the lower strain in the copper particles is indicative of this reduced $\mathrm{Cu} / \mathrm{ZnO}$ interface. Hence, less active $\mathrm{Cu} / \mathrm{ZnO}$ catalysts obtained from short-aged precipitates exhibit a larger $\mathrm{Cu}$ crystallite size, a reduced interaction between $\mathrm{Cu}$ and $\mathrm{ZnO}$, and a lower degree of microstrain in the copper crystallites.

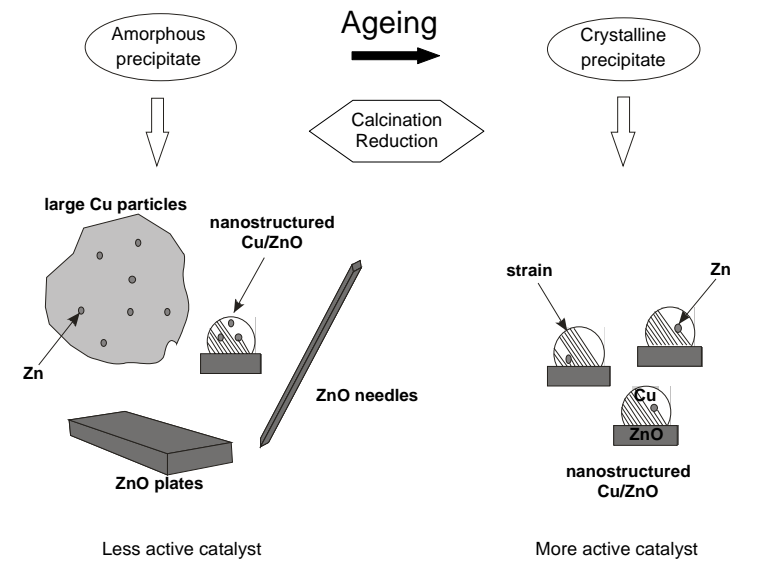

Figure 13: Schematic model of the microstructural characteristics of $\mathrm{Cu} / \mathrm{ZnO}$ catalysts obtained from differently aged precipitates (amorphous (<30 min), crystalline ( $>30 \mathrm{~min})$ ). Increasing ageing time leads to a more homogenous microstructure, a decrease in average copper crystallite size of the $\mathrm{Cu} / \mathrm{ZnO}$ catalysts, and an increase in the microstrain in the copper clusters because of the improved interface between $\mathrm{Cu}$ and $\mathrm{ZnO}$. Additionally, increased precipitate ageing results in a decreased amount of $\mathrm{Zn}$ in $\mathrm{Cu}$.
Increasing the ageing time of the precipitates $(30 \mathrm{~min}$ and $120 \mathrm{~min}$ ) results in a more homogeneous microstructure of the resulting $\mathrm{Cu} / \mathrm{ZnO}$ catalysts, which exhibits on average smaller $\mathrm{Cu}$ and $\mathrm{ZnO}$ crystallite sizes and higher copper surface areas. The improved interface between $\mathrm{Cu}$ and $\mathrm{ZnO}$ in these materials is indicated by the higher degree of microstrain in the copper crystallites. Apparently, the crystalline precipitates obtained after prolonged ageing time possess a well-defined distribution of $\mathrm{Cu}$ and $\mathrm{Zn}$ centers in the hydroxycarbonates. Upon calcinations and reduction, this results in a reduced amount of $\mathrm{Zn}$ centers in both the calcined $\mathrm{CuO} / \mathrm{ZnO}$ precursors and the reduced $\mathrm{Cu} / \mathrm{ZnO}$ catalysts. Hence, $\mathrm{Cu} / \mathrm{ZnO}$ catalysts obtained from long-aged precipitates exhibit a higher catalytic activity in methanol steam reforming that correlates with a homogeneous microstructure, a smaller $\mathrm{Cu}$ crystallite size, a narrow crystallite size distribution, and a higher degree of microstrain.

From the various methods described for the preparation of $\mathrm{Cu} / \mathrm{ZnO}$ materials (impregnation, sol-gel synthesis, hydrothermal synthesis, chemical vapour deposition, mechanical milling) co-precipitation was found to be most suitable to prepare highly active $\mathrm{Cu} / \mathrm{ZnO}$ catalysts. [39] Each precipitation parameter $(\mathrm{pH}$, temperature, solvent, precipitation agent, additives, solution composition, and ageing) as well as the post-treatment of the precipitates (washing, drying, calcination and reduction) may affect the microstructure of the resulting $\mathrm{Cu} / \mathrm{ZnO}$ catalyst. From the work described here, it emerged that the effect of precipitate ageing on copper crystallite size and microstrain of the resulting $\mathrm{Cu} / \mathrm{ZnO}$ catalyst can be readily adjusted by proper control of temperature and $\mathrm{pH}$. However, the time of transition from an amorphous to a crystalline precipitate and, hence, from a heterogeneous microstructure of a less active $\mathrm{Cu} / \mathrm{ZnO}$ catalysts to a homogeneous microstructure of a more active catalysts, may depend on the amount of precipitate formed and may deviate from the $\sim 30$ min reported here.

\section{Conclusions}

We investigated the microstructural characteristics of the copper phase in $\mathrm{Cu} / \mathrm{ZnO}$ catalysts for methanol steam reforming as a function of ageing of the precipitated hydroxycarbonates during catalyst preparation. The structureactivity correlations presented here indicate that crystallinity, phase composition, and homogeneity of the resulting hydroxycarbonate strongly influence the microstructural properties of the final copper catalyst. Hence, the structural characteristics of the precipitates as adjusted by an appropriate ageing procedure govern the properties of the final catalyst ("chemical memory" effect). The schematic model proposed for the structural characteristics of the active $\mathrm{Cu} / \mathrm{ZnO}$ catalyst as a function of precipitate ageing emphasizes the defect-rich nature of the $\mathrm{Cu}$ and $\mathrm{ZnO}$ phases in the "real" structure of $\mathrm{Cu} / \mathrm{ZnO}$ catalysts ("structural complexity") and its implication for the catalytic activity in the 
steam reforming of methanol. Formation of a homogeneous microstructure with a similar chemical composition yielded a strong increase in catalytic activity. It emerges, that microstructure design of improved heterogeneous catalysts has to start at the very first stages of catalyst preparation followed by optimizing the calcination and reduction conditions. Hence, in addition to studying structure-activity relationships of solid catalysts, the "chemical memory" of the material needs to be elucidated and considered in a rational catalyst design.

\section{References}

[1] P.J. Wild, M.J.F.M. Verhaak, Catalysis Today 60 (2000) 3.

[2] G.C. Chinchen and K.C. Waugh, Appl. Catal. 25 (1986) 101.

[3] Y. Knai, T. Wanatabe, T. Futjitani, M. Saito, J. Nakamura, T. Uchijama, Catal. Lett. 27 (1994) 67.

[4] J. Nakamura, I. Nakamura, T. Uchijama, Y. Kanai, T. Wanatabe, M. Saito, T. Fujitani, Cata. Lett. 31 (1995) 325.

[5] K. Klier, Adv. Catal. 31 (1982) 243

[6] T. Futjitani, J. Nakamura, Appl. Cata. A 191 (2000) 111.

[7] B.S. Clausen, J. Schiøtz, L. Gråbæk, C.V. Ovesen, K.W. Jacobsen, J.K. Norskov, H.Topsøe, Top. Catal. (1994) 367.

[8] J.D. Grunwaldt, A.M. Molenbroek, N.-Y. Topsøe, H. Topsøe,, B.S. Clausen, J. Catal. 194 (2000) 452.

[9] R. Burch, S.E. Golunski, J. Chem. Soc. Faraday Trans. 86 (1990) 2683.

[10] M.M. Günter, T. Ressler, B. Bems, C. Büscher, T. Genger, O. Hinrischsen, M. Muhler, R. Schlögl, Catal. Lett. 71 (2001) 37.

[11] M.M. Günter, T. Ressler. R.E. Jentoft, B. Bems, J. Catal. 203 (2001) 133.

[12] S. Sakong, A. Groß, Surface Science 525 (2003) 107.

[13] D. Waller, D. Stirling, F.S. Stone, M.S. Spencer, Farad. Disc. 87 (1989) 107.

[14] S.H. Taylor, G.J. Hutchings, A.A. Mirzaei, Catal. Today 84 (2003) 113.

[15] S.H. Taylor, G.J. Hutchings, A.A. Mirzaei, Chem. Comm. (1999) 1373.

[16] D.M. Whittle, A.A. Mirzaei, J.S.J. Hargreaves, R.W. Joyner, C.J. Kiely, S.H. Taylor, G.J. Hutchings, Phys. Chem. Chem. Phys. 4 (2002) 5915.

[17] B.L. Kniep, T. Ressler. A. Rabis, F. Steglich, M. Baenitz, F. Steglich, R. Schlögl, Angew. Chem. Int. Ed. 43 (2004) 112.

[18] B. Bems, M. Schur, A. Dassenoy, H. Junkes, D. Herein, R. Schlögl, Chem. Eur. J. 9 (2003) 2039.

[19] H. Purnama, T. Ressler, R.E. Jentoft, R. Schlögl, R. Schomäker, Appl. Catal. 259 (2004) 83.

[20] G.C. Chinchen, C.M. Hay, H.D. Vandervell, K.C. Waugh, J. Catal. 103 (1987) 79.

\section{Acknowledgement}

The authors acknowledge the ZEIT-Stiftung ("Nanotechnology for the automobiles of the future") and the Deutsche Forschungsgemeinschaft, DFG (SPP 1091 "Bridging the gaps in heterogeneous catalysis") for generous financial support. We are grateful to Bettina Bems and Michael Schur for preparing the catalyst precursors and to Herry Purnama for catalyst screening. Robert Schlögl is gratefully acknowledged for his continuous support.

[21] O. Hinrichsen, T. Genger, M. Muhler, Chem. Ing. Tech. 72 (2000) 94.

[22] J.W. Ewans, M.S. Wainright, A.J. Bridgewater, D.J. Young, Appl. Catal. 7 (1983) 75

[23] A. Szizybalski, F. Girsdies, A. Rabis, Y. Wang, M. Niederberger, T. Ressler, J.Catal. 233 (2005) 297

[24] J.I. Langford, J. Apll. Cryst. 11 (1978) 10.

[25] G.K. Williamson, W.H. Hall, Acta Met. 1 (1953) 22.

[26] T. Ressler, J. Synch. Radiat. 5 (1998) 118.

[27] T. Ressler, J. Wong, J. Roos, I.L. Smith, Environ.Sci.Technol. 34 (2000) 950.

[28] A.L. Ankudinov, B. Ravel, J.J. Rehr, S.D. Conradson, Phys Rev B58 (1998) 7565.

[29] D. Prabhakaran, A.T. Boothroyd, J. Cryst. Growth 250 (2003) 77.

[30] R.A. Brozi, S.J. Stewart, G. Punte, R.C. Mercader, R.D. Zysler, M. Tovar, Solid State Comm. 117 (2001) 311.

[31] B.S. Clausen, L. Gråbæk, H. Topsøe, L.B. Hansen, P. Stoltze, J.K. Nørskov, J. Catal. 141 (1993) 368.

[32] T. Ressler, B.L. Kniep, I. Kasatkin, R. Schlögl, Angew. Chem. Int. Ed. 44 (2005) 2.

[33] J. Sloczynski, R. Grabowski, A. Kozlowska, P. K. Olszewski, J. Stoch, Phys. Chem. Chem. Phys. 5 (2003) 4631.

[34] J.Y. Kim, J.A. Rodriguez, J. C. Hanson, A.I. Frenkel, P.L. Lee, J. Am. Chem. Soc. 125 (2003) 10684.

[35] M. Kurtz, H. Wilmer, T Genger, O. Hinrichsen, M. Muhler, Catal. Lett. 86 (2003) 77.

[36] J.B. Wagner, P.L. Hansen, A.M. Molenbroek, H. Topsoe, B.S. Clausen, S. Helveg, J. Phys. Chem. B 107 (2003) 7753.

[37] F. Girgsdies, T. Ressler, U. Wild, T. Wübben, T.J. Balk, G. Dehm, L. Zhou, S. Günther, E. Arzt, R. Imbihl, R. Schlögl, Catal. Lett., 102 (2005) 91.

[38] M.S. Spencer, Surface Science 192 (1987) 323.

[39] J.P. Shen, C. Song, Catal. Today 77 (2002) 89. 